\title{
MENGURAI KONSEP DASAR MANUSIA SEBAGAI INDIVIDU MELALUI RELASI SOSIAL YANG DIBANGUNNYA
}

\author{
Oleh: \\ Meilanny Budiarti S.
}

\begin{abstract}
ILUSTRASI
Pukul 8.35 suatu pagi waktu jam sekolah, satu ambulan memasuki rumah sakit, membawa seorang anak yang terluka parah. Seorang pengantar terlihat mengurusi anak dan menemui petugas rumah sakit.

Sang pengantar kemudian diajak bicara oleh seorang pekerja sosial. Diketahui bahwa dia petugas sekolah, dan anak tersebut salah satu siswanya yang mengalami tabrakan, karena mengendarai motor sediri; anak tersebut jarang bergaul, tidak memiliki teman, sering menyendiri dan jarang bicara.

Tidak lama kemudian orang tuanya datang. Keluarga tersebut baru pindah 1 tahun yang lalu membawa 4 anaknya untuk memperbaiki hidupnya. 3 bulan terakhir kondisi ekonomi keluarga tersebut sedang menurun. Bahasa, etnis, agama, dan komunitas secara keseluruan seolah telah menciptakan barrier bagi keluarga tersebut. Motor yang disediakan bagi anak tersebut dengan harapan mampu mendukung belajarnya.

Pada malam hari si anak meninggal, dan pekerja sosial telah mencoba menenangkan keluarga tersebut.
\end{abstract}

Dalam keadaan demikian, sang pekerja sosial merenung, dan bertanya pada dirinya; mengapa tragedi ini bisa terjadi? Apa yang dapat saya lakukan sekarang untuk membantu keluarga tersebut?

Ilustrasi tersebut di atas, sangat mungkin kita temui di tengah kehidupan bermasyarakat. Ada beragam cerita kehidupan yang mau tidak mau harus dijalani oleh masing-masing orang sebagai diri individu manusia.

Berbicara tentang manusia, apa sebenarnya hakekat dasar manusia? Pemikiran ini tentunya sangat penting untuk kita pahami dalam memandang diri individu seorang manusia. Terlebih dalam terlebih dalam memahami manusia di tengah-tengah kehidupan bermasyarakat.

Hakekat dasar manusia dapat dipahami berdasarkan karakteristik diri manusia itu sendiri. Berbagai karakteristik manusia dapat dipahami sebagai berikut:

1) Manusia sebagai makhluk individu
Sebagai makhluk individu, manusia memiliki keunikan tersendiri, yang membedakannya dari manusia lainnya. Dalam pandangan ini, manusia menjadi individu yang tidak dapat dipandang sama, karena secara kodrati setiap manusia diciptakan unik dan berbeda satu dengan yang lainnya. Berikut ini beberapa rincian dalam memandang keunikan yang dimiliki manusia:

a. Setiap manusia mempuyai kemampuan berfikir (kognisi), perasaan (afeksi), kehendak (konasi), dan tindakan (aksi)

b. Setiap manusia memiliki kemampuan khas yang akan mempengaruhi kualitas hidupanya: berupa pengetahuan, keterampilan dan sikap 
c. Setiap manusia mempunyai budaya tertentu sesuai dengan latar belakang, kapasitas dan lingkungannya

d. Bahwa setiap manusia mempunyai hak dan kewajiban yang terkait dengan pihak lain

2) Manusia sebagai makluk berkebutuhan

Setiap diri individu manusia diciptakan di dunia dengan segala kebutuhannya. Hal ini ditandai dengan menangisnya seorang bayi pada saat dilahirkan. Itu penanda adanya kehidupan dan disana pulalah tercipta kebutuhan; kebutuhan untuk dilindungi, kebutuhan akan rasa aman dan berbagai bentuk kebutuhan lainnya. Keragaman kebutuhan yang di miliki oleh setiap individu sangat beragam, sesuai dengan tingkatan dan keadaan dari setiap individu tersebut.

Satu teorema terkemuka terkait dengan kajian tentang kebutuhan manusia, yaitu hierarkhi kebutuhan dari Maslow.
Menurut Maslow;

$\checkmark$ Setiap individu dimotivasi oleh kebutuhan yang 'unsatisfied'

Statement tersebut menunjukkan kepada kita bahwa setiap manusia tidak akan pernah puas untuk memenuhi kebutuhannya. Mengapa demikian? Jawabannya terkait dengan statement berikutnya:

$\checkmark$ Saat tiap kebutuhan terpenuhi, maka hal tersebut akan men-drives dan menforces pada kebutuhan berikutnya Hal tersebut adalah ciri dan tabi'at manusia, tentunya bagi siapapun yang tidak dapat mengendalikan drives tersebut, maka akan menjerumuskan manusia pada sifat serakah yang akan men-forces manusia untuk terus dan terus hingga seakan tiada akhirnya (tidak pernah puas) dan menjadi pintu datangnya permasalahan.

\section{Maslow's Hierarchy of}

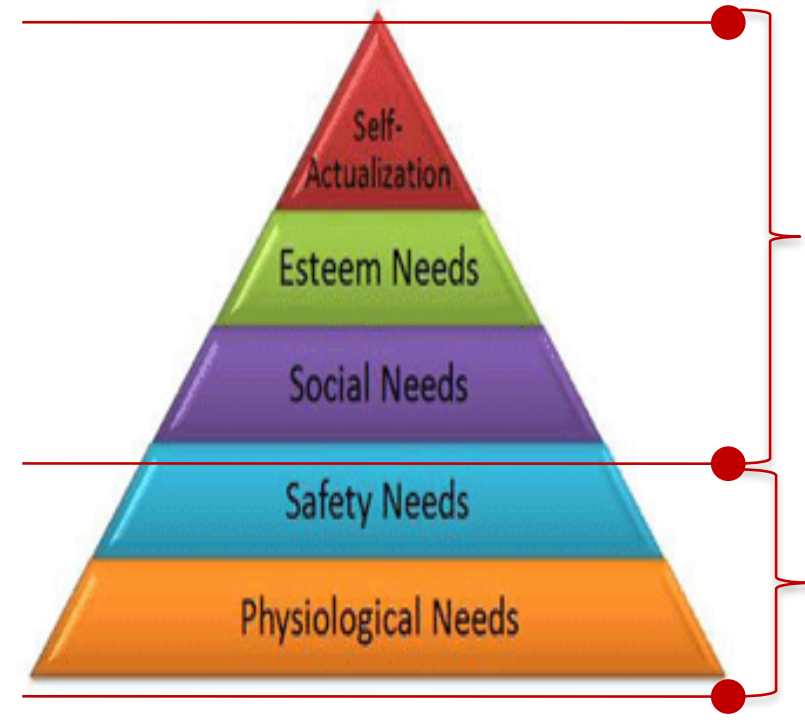

\section{Higher-order needs}

$\checkmark$ These higher-order needs are generally satisfied internally, i.e., within an individual.

\section{Lower-order needs.}

These lower-order needs are mainly satisfied externally.

Maslow's hierarchy of needs di atas menunjukkan pada kita bahwa terdapat tingkatan kebutuhan manusia, mulai dari physiological needs sebagai tingkatan terbawah pada hierarkhi kebutuhan manusia, tingkatan berikutnya adalah safety needs.
Kedua tingkatan kebutuhan merupakan kebutuhan dasar bagi manusia yang pemenuhan kepuasannya bergantung pada faktor eksternal, yang berasal dari luar diri individu. 
Adapun tingkatan berikutnya dari maslow's hierarchy of needs adalah social needs, esteem needs dan self-actualization. Ketiga tingkatan kebutuhan yang terakhir ini merupakan kebutuhan tingkat lanjut (atas) yang pemenuhan kepuasannya bergantung pada faktor internal, yang berasal dari dalam diri individu itu sendiri.

Manusia dalam memenuhi kebutuhannya akan menciptakan hubungan sosial. Hal ini sejalan dengan keberadaan manusia sebagai makhluk sosial yang diciptakan ke muka bumi oleh Sang Pencipta melalui kelahiran atas kasih sayang kedua orang tuanya kita. Setiap manusia akan menjalin hubungan sosial, minimal dengan orang terdekatnya, yaitu orang tua dan keluarganya. Berikutnya dalam interaksinya sebagai makhluk sosial, manusia akan membentuk satuan-satuan suku-suku hingga bangsa-bangsa di berbagai belahan bumi.

\section{Lingkungan (budaya, teknologi) akan turut} mempengaruhi bentuk dan jenis relasi sosial. Hal ini sangat dapat kita pahami, sejalan dengan kemajuan budaya dan teknologi yang diciptakan oleh akal pikir manusia, telah mendorong terciptanya lingkungan yang maju dengan segala kompeksitasnya. Dengan kemajuan budaya, manusia terus memproduksi berbagai ide, karya dan estetika dalam kehidupan bermasyarakat. Tentunya hal ini akan sejalan dengan teknologi yang semakin canggih sebagai buah dari ilmu pengetahuan yang dikembangkan oleh manusia.

Namun sayang, dibalik berbagai kemajuan yang telah diciptakan oleh manusia, muncul pula berbagai permasalahan sosial sebagai bagian dari hasil hubungan dan relasi sosial yang terbentuk antarmanusia.

3) Manusia sebagai makhluk sosial

Sebagai makhluk sosial, setiap manusia memerlukan pihak lain untuk melangsungkan hidupnya

$\checkmark$ H. Booner (dalam bukunya Social Psychology) menyatakan bahwa: "Interaksi sosial adalah hubungan antar dua individu atau lebih, di mana kelakuan individu yang satu mempengaruhi, mengubah, atau memperbaiki kelakuan individu yang lain atau sebaliknya."

Statement di atas menunjukkan kepada kita bahwa setiap manusia memiliki potensi untuk terus belajar dan ini adalah anugerah terbesar yang dititipkan Sang Pencipta kepada setiap manusia.

Proses belajar pada diri manusia dapat terjadi baik itu melalui proses yang disadari ataupun dalam proses di bawah alam sadar, itulah bukti kecerdasan tubuh manusia yang dapat merespons setiap apapun yang terjadi pada lingkungannya.

Tentunya, harapannya adalah setiap interaksi sosial dan hubungan antar dua individu atau lebih, di mana kelakuan individu yang satu akan mempengaruhi, mengubah, atau memperbaiki kelakuan individu yang lain atau sebaliknya ke arah yang lebih positif dan mendatangkan manfaat kepada perubahan dan peradaban manusia yang lebih baik dari masa ke masa, tidak sebaliknya.

$\checkmark$ Gillin dan Gillin (1954) menyatakan bahwa interaksi sosial adalah hubunganhubungan antara orang-orang secara individual, antar kelompok orang, dan orang perorangan dengan kelompok

Statement Gillin dan Gillin (1954) di atas, menunjukkan bahwa menusia pun memiliki kecenderungan untuk berkelompok sesuai dengan satu atau beberapa kesamaan yang dimiliki oleh anggota kelompoknya.

4) Manusia sebagai makhluk susila

Maknanya adalah bahwa manusia diciptakan sebagai makhluk yang bermoral dan sadar akan norma dan nilai-nilai

$\checkmark$ Manusia senang dengan keteraturan sehingga akan selalu menciptakan aturan, norma dan nilai-nilai hidup yang menjadi acuan hidupnya

Hal ini terepresentasi dalam kehidupan bermasyarakat, di mana selalu ada 
aturan, norma dan nilai yang menjadi acuan dan pedoman bersama bagi setiap anggota masyarakatnya.

$\checkmark$ Thomas Hobbes menyatakan bahwa salah satu hakikat manusia adalah keberadaan kontrak sosial, yaitu setiap orang harus menghargai dan menjaga hak orang lain. Manusia sebagai makhluk sosial ditandai dengan keberadaan kontrak sosial di dalamnya.

Dalam kehidupan bermasyarakat; kontrak sosial muncul dalam bentuk aturan, norma dan nilai-nilai hidup yang harus dipatuhi dan ditaati oleh setiap masyarakat

$\checkmark$ Manusia tidak dapat menjalani kehidupannya secara sendiri-sendiri, oleh karena itu harus ada saling menghargai antar sesama dan saling menjaga hak-hak orang lain.

Dalam praktik pekerjaan sosial, seorang pekerja sosial dalam menggunakan pendekatan berbasis hak dapat dilaksanakan berdasarkan tiga generasi hak, yaitu hak sipil dan politik, hak ekonomi sosial dan budaya, serta hak kolektif. Dengan menggunakan pendekatan berbasis hak, pekerja sosial telah mengangkat harkat dan martabat klien sebagai individu manusia dan mendorong setiap individu untuk berperan aktif dalam mengidentifikasi serta menggunakan potensi yang ada pada diri dan lingkungannya untuk menghadapi tantangan yang mereka alami. Praktik pekerjaan sosial dengan berdasarkan hak akan membantu individu dalam mengatasi tantangan keberfungsian sosial klien dan memfasilitasi klien untuk mendapatkan keadilan sosial.

\section{Manusia dan Relasi Sosial}

$\checkmark$ Hakekat dasar manusia (terutama sebagai makhluk sosial dan berkebutuhan) akan mewujudkan relasi sosial.

Manusia sebagai makhluk sosial dan makhluk berkebutuhan, tentunya tidak akan bisa hidup seorang diri, terlebih untuk memenuhi berbagai kebutuhannya sendiri. Oleh karena itu, manusia akan selalu membentuk dan memelihara relasi sosial agar mereka dapat saling tolong menolong dan saling meringankan dalam upaya memenuhi berbagai kebutuhan hidupnya.

$\checkmark$ Relasi sosial bisa berjenjang tingkatannya; tetapi esensinya tetap individu yang berperan

Dalam menjalankan relasi sosial, seberapa banyak ikatan yang dibangun dalam sebuah kelompok, masyarakat, bahkan bernegara; maka sejatinya tetap individulah kuncinya, yaitu untuk berperan dalam menjalankan dan memfungsikan berbagai relasi sosial tersebut.

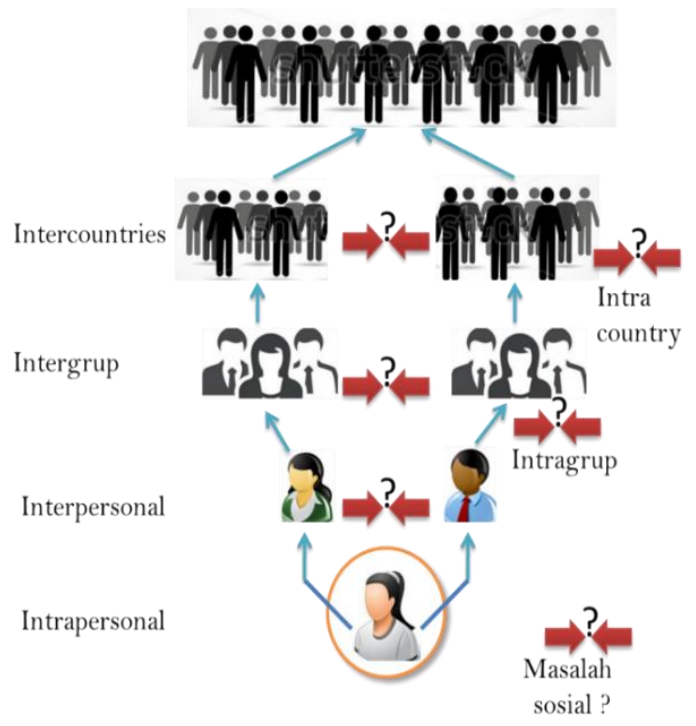

Resiko Berelasi Sosial

(1) Karena karakter, kapasitas, serta kebutuhan setiap individu bersifat khas, maka pada saat sekelompok manusia berelasi akan menciptakan kondisi kohesif dan adhesive.

Dengan kekhasan yang dimiliki oleh masing-masing individu manusia, tentunya hal ini akan menjadi potensi untuk saling menguatkan dalam memenuhi setiap kebutuhan manusia. Namun, apabila yang terjadi adalah yang sebaliknya, yaitu ketika seseorang tidak bisa menerima beragam kekhasan setiap 
individu, tidak mau mengerti ataupun tidak bisa menyesuaikan diri dengan beragam kekhasan yang dimiliki oleh masing-masing individu, maka situasi seperti inilah yang kemudian bagi sebagian orang kemudian dirasakan sebagai sebuah permasalahan.

Tentunya ketidakterimaan terhadap kekhasan setiap individu manusia seperti di atas sejak awal sudah menyalahi hukum alam dalam memandang individu manusia. Sudah benar bila kemudian hal tersebut menjadi permasalahan, karena menyalahi hukum dasar dalam memandang fitrah manusia yang diciptakan dengan beragam kekhasannya masing-masing.

(2) Kondisi kohesif akan saling menguatkan kualitas individu yang pada akhirnya akan meningkatkan kualitas sosial

Situasi seperti ini adalah yang diharapkan terjadi pada relasi sosial yang terbentuk dari setiap individu. Tentunya dibutuhkan waktu yang panjang untuk dapat membentuk relasi sosial seperti ini, karena setiap proses yang terjadi pada relasi sosial antarindividu akan menjadi media bagi mereka untuk saling belajar guna menguatkan kualitas individu yang ada, sehingga pada akhirnya akan meningkatkan kualitas sosial.

(3) Kondisi adhesif yang tidak kompromistik akan mendegradasikan kualitas setiap individu dan pada akhirnya menciptakan kondisi destruktif; yang akan mengeliminasi relasi sosial; bahkan bisa berbalik menjadi konfrontasi rasial.

Tentunya situasi seperti ini sangat tidak diharapkan terjadi dalam relasi sosial antarindividu. Seperti yang telah diuraikan sebelumnya, kondisi adhesif ini dapat terjadi ketika seseorang tidak bisa menerima beragam kekhasan setiap individu, tidak mau mengerti ataupun tidak bisa menyesuaikan diri dengan beragam kekhasan yang dimiliki oleh masing-masing individu.
(4) Perlu usaha recovery terhadap individu atau kelompok yang mengalami 'kerusakan' akibat buruknya interaksi sosial

Setiap 'kerusakan' dan masalah sosial terjadi sebagai akibat buruk dari interaksi sosial antarindividu, individu dengan kelompok ataupun antara kelompok dengan kelompok. Terhadap 'kerusakan' dan masalah sosial yang muncul tersebut, tentunya perlu upaya recovery terhadap individu atau kelompok yang terlibat.

Dalam situasi demikian, profesi pekerjaan sosial dapat berperan untuk memberikan pelayanan bagi individu, kelompok ataupun masyarakat tersebut. Walaupun, penanganan masalah bukan satu-satunya fokus praktik dari profesi pekerjaan sosial, karena profesi pekerjaan sosial justru lebih fokus pada upaya membangun kapasitas diri individu, kelompok dan masyarakat untuk dapat menggunakan berbagai sistem sumber dalam menangani masalah yang mereka hadapi, sesuai dengan prinsip helping people to help themselves.

Dengan berbekal berbagai pemahaman dasar mengenai karakteristik manusia tersebut, para pekerja sosial dapat melakukan praktik pelayanan pekerjaan sosial secara professional terhadap klien dengan lebih baik. Terutama dalam melakukan proses asesmen terhadap klien serta memahami setiap informasi dan data yang didapatkan terkait keberadaan klien dengan segala permasalahan dan berbagai sistem sumber yang dimiliki ataupun ada dalam lingkungannya. Tentunya, semua itu ditujukan untuk memperbaiki dan meningkatkan keberfungsian sosial individu dalam membangun dan mempertahankan relasi sosial yang mereka miliki untuk kehidupan yang lebih baik.

\section{Sumber bacaan:}

Maslaw, Abraham H., Motivasi dan Kepribadian: Teori Motivasi dengan Ancangan Hirarki Kebutuhan Manusia (judul asli: Motivation and Personality), diterjemahkan oleh Nurul Iman, 1984, Jakarta: PT. Pustaka Binaman Pressindo. 
Skidmore, Rex A., Milton Thackeray, dan o. William Farley, 1988. Introduction to Social Work. New Jersey: Simon \& Scuster Englewood Cliffs.

Zastrow, Charles. 1982. Introduction to Social Welfare Institutions: Social Problems,
Service and Current Issues. Homewood: Dorsey Press. 